\title{
Assessing glomerular filtration rate in healthy adult potential kidney donors in Bangladesh: A comparison of various prediction equations with measured glomerular filtration rate by diethylentriamine pentaacetic acid renogram
}

\author{
Jahan $\mathrm{F}^{1}$, Chowdhury MNU ${ }^{1}$, Mahbub $\mathrm{T}^{1}$, Arafat $\mathrm{SM}^{2}$, Jahan $\mathrm{S}^{2}$, Hossain $\mathrm{M}^{1}$, Khan $\mathrm{MF}^{1}$ \\ ${ }^{l}$ Department of Nephrology, Dhaka Medical College \& Hospital (DMC\&H), Dhaka, \\ ${ }^{2}$ Department of Medicine, Bangabandhu Sheikh Mujib Medical University (BSMMU), Dhaka. \\ Email: ferdousjahan1999@yahoo.com
}

\begin{abstract}
To ensure that potential kidney donors in Bangladesh have no renal impairment, it is extremely important to have accurate methods for evaluating the glomerular filtration rate (GFR). We evaluated the performance of serum creatinine based GFR in healthy adult potential kidney donors in Bangladesh to compare GFR determined by DTPA with that determined by various prediction equations. In this study GFR in 61 healthy adult potential kidney donors were measured with $99^{\mathrm{m}} \mathrm{Tc}$-diethylenetriamine penta-acetic acid (DTPA) renogram. We also estimated GFR using a four variable equation modification of diet in renal disease (MDRD), Cockcroft-Gault creatinine clearance $(\mathrm{CG} \mathrm{CrCl})$, Cockcroft-Gault glomerular filtration rate (CG-GFR). The mean age of study population was $34.31 \pm 9.46$ years and out of them $65.6 \%$ was male. In this study mean mGFR was $85.4 \pm 14.8$. Correlation of estimated GFR calculated by CG-CrCl, CG-GFR and MDRD were done with measured GFR DTPA using quartile. Kappa values were also estimated which was found to be 0.104 for $(p=0.151), 0.336$ for $(p=0.001)$ and 0.125 for $(p=0.091)$ respectively. This indicates there is no association between estimated GFR calculated by CG-CrCl, CG-GFR, MDRD with measured GFR DTPA. These results show poor performance of these equations in evaluation of renal function among healthy population and also raise question regarding validity of these equations for assessment of renal function in chronic kidney disease in our population.
\end{abstract}

\section{Introduction}

Measurement of GFR is the most widely accepted standard for the assessment of renal function in heath and disease ${ }^{1}$. GFR can be precisely measured by using the filtration markers like inulin clearance which is the gold standard but it is cumbersome, costly and no readily available. The Tc- $99^{\mathrm{m}}$ diethylentriamine pentaacetic acid (DTPA) clearance to measure GFR correlate well with results of inulin clearance and have been used to measure GFR in clinical practice $\mathrm{e}^{2-4}$. But the time interval needed for acquiring the multiple blood samples, which may be up to 4 hours, combined with sample counting and subsequent back extrapolation of data to determine the radionuclide clearance rate, impose logistical constraints on a busy nuclear medicine department. Alternatively measuring clearance of $\mathrm{Tc}-99^{\mathrm{m}}$ DTPA using a single blood sample instead of multiple samples has lead to less accurate results ${ }^{5}$. Considering these problem Camera-based methods for measuring renal uptake of Tc-99m DTPA without blood or urine sampling method is more precise for GFR estimation at all levels of renal function ${ }^{\mathbf{6}, 7}$. The method introduced by Gates (1983) has been the most common routine method ${ }^{8}$.

National Kidney Foundation $\left(\mathrm{NKF}^{\mathrm{TM}}\right)^{\mathbf{9}}$ has suggested to estimate-GFR (eGFR) by the abbreviated Modification of Diet in Renal Disease (MDRD) and Cockcroft-Gault (C-G) equation. But all these equations were derived predominantly from the Caucasian population suffering from varying degrees of chronic kidney disease. There is also striking difference in anthropometric measurements in the Cockcroft-Gault and MDRD study between the North American and the South Asian population ${ }^{\mathbf{1 0}}$.

This study was intended to assess GFR among adult healthy donors by DTPA renogram, and also to compare this result with the e-GFR calculated by prevailing equations.

Rationale of the study: Estimated GFR (eGFR) by the abbreviated Modification of Diet in Renal Disease (MDRD) and Cockcroft-Gault (C-G) equation has been the tool chosen by the $\mathrm{NKF}^{\mathrm{TM}}$. All these equation were derived predominantly from the Caucasian population suffering from 
varying degrees of chronic kidney disease. There is a striking difference in anthropometric measures between the Cockcroft-Gault and MDRD study cohort and the south Asian population like our Bangladesh. In potential kidney donors, prediction equations may not be sufficient for estimating GFR. Therefore $\mathrm{Tc} 99^{\mathrm{m}} \mathrm{DTPA}$ renogram studies are needed for accurate measurement of GFR.

Therefore we need to know average GFR of our healthy adult Bangladeshi people and also essential to know whether the prediction equation based estimation of GFR is valid for Bangladeshi population or not.

So therefore only a few studies have been carried out to know average GFR of healthy Bangladeshi population based on prediction equation but validation of formula based eGFR with standard method of measured GFR not done yet in our country.

\section{Materials and Methods}

This observational study was carried out in the Department of Nephrology, Dhaka Medical College Hospital, and Kidney Foundation, Dhaka. Bangladesh from November 2010 to October, 2011.

Study population: After addressing the ethical issues, healthy adults who decided to donate their kidney in study area according to organ donation legal requirement of Bangladesh were included in this study

Selection criteria: All the adult healthy potential kidney donors of the defined area, age 18 to 65 years, both genders, and who consented to participate in the study were included in the study. Potential donors outside this age group, or who did not consent to participate in the study were excluded.

Sampling method: Sampling was done by convenience sampling.

Sample size: The sample size for a cross-sectional study was determined using

$$
n=\frac{z^{2} p q}{d^{2}}
$$

where,

$n$ is the sample size,

$z$ is the standard normal value corresponding to the confidence level considered,

$p$ is the probability of prevalence,

$q=1-p$, and

$d$ is the error level.

For the case of our study, we require to modify the formula for determination of the sample size. To do this, we re-write the formula as $n^{2}=\frac{z^{2} n p q}{d^{2}}$
Since the outcome of each sample would be either success or failure, the statistical event can be considered to be a Bernoulli trial; hence the experiments a binomial experiment. Therefore, $n p q$ is the square of the standard deviation. Therefore,

$$
\text { or } \begin{gathered}
n^{2}=\frac{z^{2} \sigma^{2}}{d^{2}} \\
n=\frac{z \sigma}{d}
\end{gathered}
$$

This formula will form the basis for determination of a sample size. To estimate the standard deviation, we consider Mahajan, et al. ${ }^{11}$ We only had 61 samples for the period of the study. Therefore, our sample size was going to be constrained by availability The study was conducted on approximately available samples. The data were collected through a detailed proforma completed for each case and range, mean, standard deviation, ratios and percentages were calculated through SPSS program version 16.0. The qualitative data of were measured by Chi square test or and quantitative data were analyzed by unpaired $t$-test. Correlation of estimated CG-CCr, estimated CGGFR and estimated MDRD with measured GFR was calculated by Kappa test. A guideline for how Kappa might be interpreted ${ }^{23}$ is given in Table I.

Measures of Variables: Socio demographic data including age, sex, body weight, height, body surface area were collected for each donor. Investigations for Serum creatinine, ${ }^{99 \mathrm{~m}}$ Tc-DTPA renogram were similarly conducted for each donor.

Laboratory Investigation: Serum Creatinine: Serum creatinine was measured by Jaffe modified kinetic alkaline picrate method. $\mathrm{NaOH}(\mathrm{R} 1)$ and Picric acid (R2) reagents were used. Both the reagents were made by Plasmatech, France. $500 \mu \mathrm{mol} / \mathrm{L}$ of both regents were taken and added with $100 \mu \mathrm{mol} / \mathrm{L}$ of sample. The resulting solution was then analyzed either on Echo auto analyzer, made in Italy or on Mindray semi auto analyzer made in Germany (model no BA 88A). This test was carried out Kidney Foundation Lab, Dhaka

99mTc DTPA Renogram with split renal function: DTPA Renogram study was conducted on E-Cam, Dual Head SPECT Gamma Camera, manufactured by Siemens, Germany. Study subject was required to be on normal diet and well hydrated orally for 30 minute before study initiation. $5 \mathrm{mCi}$ Tc99 ${ }^{\mathrm{m}}$-DTPA was injected intravenously and dynamic images of kidneys were taken in total 147 frames. Total study time was 30 minute. The calculated DTPA GFR was used as the measured GFR and standardized for a body surface area (BSA) of $1.73 \mathrm{~m}^{2} .99^{\mathrm{m}} \mathrm{Tc}$ DTPA Renogram with split renal function was 
carried out at Nuclear and USG Department of Atomic Energy Commission, Dhaka Medical College campus.

\section{Operational Definition:}

Estimated GFR was calculated using the following formula.

1. Cockcroft Gault formula:

A. $\mathrm{C}-\mathrm{GCCr}=\frac{(140-\text { Age }) \times \text { Body Weight }(\mathrm{kg})}{72 \times \text { SerumCreatinine }(\mathrm{mg} / \mathrm{dl})}$

If female multiply with .85

- Creatinine clearance is expressed $\mathrm{ml}$ per minute

- Age in years

- Weight in kilograms

- Serum creatinine in milligrams per deciliter

$$
\begin{aligned}
\text { B.C-G GFR }= & \text { C-GCCr } \times .84^{11,12,13} \\
\text { 2. MDRD eGFR= } & 186 \times[\mathrm{S} . \mathrm{cr}]^{-1.154} \times[\text { Age }]-0.203 \times \\
& {[0.742 \text { if pt. is female }] \times[1.212} \\
& \text { if pt. is black }]^{14,15}
\end{aligned}
$$

Detailed procedure: Healthy adult who decided to donate their organ (kidney) in study area according to organ donation legal requirement of Bangladesh. Necessary clinical history, physical examination and investigation including blood group, $\mathrm{HB}_{\mathrm{s}} \mathrm{Ag}$, AntiHCV, HIV, VDRL, CMV-IgG, CMV-IgM, UrineR/M/E, Urine for culture and sensitivity, UTP/UTV, serum creatinine, serum urea, serum electrolyte, complete blood count, ESR, blood sugar-Fasting, liver function test-serum bilirubin, serum total protein, prothrobin time, SGPT, serum Albumin, X-ray chest P/A view, ECG, Ultrasonogram of whole abdomen to special attention to KUB region, Thyroid function test-total $\mathrm{T}_{4}, \mathrm{TSH}$, HLA typing, Direct tissue matching and cytotoxicity, CT Renal Angiogram, Estimated GFR from (C-G formula, MDRD), $99^{\mathrm{M}} \mathrm{Tc}$ DTPA Renogram with split renal function was carried out by Nuclear and USD department of Atomic Energy.

Height and weight was measured.

Height was measured with a conventional measuring tape in centimeter.

Weight was measured with an analog machine in kilogram.

\section{Results}

A total of 61 donors were considered in this study.out of them were 40 male and 21 female. The characteristics of the donors are shown in Table II. The table shows that mean age of the donors was $34.31 \pm 9.46$ years, mean weight was $55.21 \pm 11.18$ kilogram, mean height was 160.06 \pm 9.24 centimeters, mean body surface area was $1.56 \pm$ $0.18 \mathrm{~m}^{2}$, mean body mass index was $21.56 \pm 4.20$. Table III shows that mean serum creatinine is $0.93 \pm 0.13 \mathrm{mg} / \mathrm{dl}$, mean 99mTc-DTPA Renogram mGFR was $85.40 \pm 14.79$, mean Corrected CG-CrCl was $77.87 \pm 27.80 \mathrm{ml} / \mathrm{min}$, mean Corrected CG-GFR was $71.65 \pm 20.01 \mathrm{ml} / \mathrm{min}$, and mean MDRD GFR was $84.17 \pm 18.81 \mathrm{ml} / \mathrm{min}$.

A comparison of estimated CG-CCr with measured GFR DTPA is shown in Table IV. The results are grouped according to quartile. The results of the interpreter analysis are Kappa $=0.104$ with $p=0.151$. This measure of agreement, while not statistically significant, is slight agreement.

A comparison of estimated CG-GFR with measured GFR DTPA grouped by quartile is shown in Table V. The results of the interpreter analysis are Kappa $=0.366$ with $p=0.001$. This measure of agreement, while statistically significant, but it is in fair agreement.

A comparison of estimated MDRD with measured GFR DTPA grouped by quartile is shown in Table VI. The results of the interpreter analysis are Kappa $=0.125$ with $p=0.091$. This measure of agreement, while statistically not significant, but is in slight agreement.

Table I: Guideline to interpret Kappa

\begin{tabular}{ll}
\hline Kappa & Interpretation \\
\hline$<0$ & Poor agreement \\
$0.0-0.20$ & Slight agreement \\
$0.21-0.40$ & Fair agreement \\
$0.41-0.60$ & Moderate agreement \\
$0.61-0.80$ & Substantial agreement \\
$0.81-1.00$ & Almost perfect agreement \\
\hline
\end{tabular}

Table II: General characteristics of the donors

\begin{tabular}{lcccc}
\hline & Male & Female & Total & P value \\
\hline Age (years) & $32.0 \pm 8.63$ & $38.71 \pm 9.61$ & $34.31 \pm 9.46$ & 0.007 \\
Weight (kilograms) & $57.28 \pm 10.1951 .29 \pm 12.15$ & $55.21 \pm 11.18$ & 0.045 \\
Height (cm) & $165.68 \pm 4.95$ & $149.36 \pm 4.98$ & $160.06 \pm 9.24$ & 0.001 \\
BSA $\left(\mathrm{m}^{2}\right)$ & $1.62 \pm 0.15$ & $1.45 \pm 0.17$ & $1.56 \pm 0.18$ & 0.001 \\
BMI & $20.81 \pm 3.14$ & $23.01 \pm 5.51$ & $21.56 \pm 4.2$ & 0.051 \\
\hline
\end{tabular}

Table III: Mean distribution of serum Creatinine, 99m TcDTPA renogram, estimated CG-CCr, estimated CG-GFR and estimated GFR (MDRD) of the study population $(n=61)$

\begin{tabular}{lcccc}
\hline & Male & Female & Total & P value \\
\hline Serum Creatinine $(\mathrm{mg} / \mathrm{dl})$ & $1.0 \pm 0.1$ & $0.9 \pm 0.1$ & $0.9 \pm 0.1$ & $0.001^{\mathrm{s}}$ \\
\hline $\begin{array}{l}\text { Estimated CG-CCr } \\
\left(\mathrm{ml} / \mathrm{min} / 1.73 \mathrm{~m}^{2}\right)\end{array}$ & $85.7 \pm 27$ & $63 \pm 23.4$ & $77.9 \pm 27.8$ & $0.001^{\mathrm{s}}$ \\
\hline $\begin{array}{l}\text { CG-GFR Estimate } \\
\left(\mathrm{ml} / \mathrm{min} / 1.73 \mathrm{~m}^{2}\right)\end{array}$ & $72 \pm 22.6$ & $71 \pm 14.4$ & $71.6 \pm 20.1$ & $0.854^{\mathrm{ns}}$ \\
\hline $\begin{array}{l}\text { Estimated GFR }(\mathrm{MDRD}) \\
\left(\mathrm{ml} / \mathrm{min} / 1.73 \mathrm{~m}^{2}\right)\end{array}$ & $92.2 \pm 16.1$ & $68.9 \pm 13.6$ & $84.2 \pm 18.8$ & $0.001^{\mathrm{s}}$ \\
\hline $\begin{array}{l}\text { 99 TcDTPA Renogram } \\
\left(\mathrm{ml} / \mathrm{min} / 1.73 \mathrm{~m}^{2}\right)\end{array}$ & $85.9 \pm 13.6$ & $84.5 \pm 17.1$ & $85.4 \pm 14.8$ & $0.728^{\mathrm{ns}}$ \\
\hline
\end{tabular}


Table IV: Association between measured GFR DTPA with estimated CG-CCr $(n=61)$

\begin{tabular}{|c|c|c|c|c|c|c|c|c|c|c|}
\hline \multirow{3}{*}{$\begin{array}{l}\text { Estimated } \\
\text { CG-CCr } \\
(\mathrm{ml} / \mathrm{min} / 1.7 \\
\left.3 \mathrm{~m}^{2}\right)\end{array}$} & \multicolumn{10}{|c|}{ Measured GFR DTPA $\left(\mathrm{ml} / \mathrm{min} / 1.73 \mathrm{~m}^{2}\right)$} \\
\hline & \multicolumn{2}{|c|}{$\begin{array}{c}1^{\text {st }} \\
\text { quartile } \\
(n=15)\end{array}$} & \multicolumn{2}{|c|}{$\begin{array}{c}2^{\text {nd }} \\
\text { quartile } \\
(n=16)\end{array}$} & \multicolumn{2}{|c|}{$\begin{array}{c}3^{\text {rd }} \\
\text { quartile } \\
(n=15)\end{array}$} & \multicolumn{2}{|c|}{$\begin{array}{c}4^{\text {th }} \\
\text { quartile } \\
(n=15)\end{array}$} & \multicolumn{2}{|c|}{$\begin{array}{l}\text { Total } \\
(n=61)\end{array}$} \\
\hline & $\mathrm{n}$ & $\%$ & $\mathrm{n}$ & $\%$ & $\mathrm{n}$ & $\%$ & $\mathrm{n}$ & $\%$ & $\mathrm{n}$ & $\%$ \\
\hline $1^{\text {st }}$ quartile & 6 & 40.0 & 3 & 18.8 & 6 & 40.0 & 0 & 0.0 & 15 & 24.6 \\
\hline $2^{\text {nd }}$ quartile & 5 & 33.3 & 4 & 25.0 & 3 & 20.0 & 4 & 26.7 & 16 & 26.2 \\
\hline $3^{\text {rd }}$ quartile & 2 & 13.3 & 4 & 25.0 & 4 & 26.7 & 5 & 33.3 & 15 & 24.6 \\
\hline $4^{\text {th }}$ quartile & 2 & 13.3 & 5 & 31.3 & 2 & 13.3 & 6 & 40.0 & 15 & 24.6 \\
\hline
\end{tabular}

Table V: Association between measured GFR DTPA with estimated CG-GFR $(n=61)$

\begin{tabular}{|c|c|c|c|c|c|c|c|c|c|c|}
\hline \multirow{3}{*}{$\begin{array}{l}\text { Estimated } \\
\text { CG- } \\
\text { GFR }(\mathrm{ml} / \mathrm{min} \\
\left./ 1.73 \mathrm{~m}^{2}\right)\end{array}$} & \multicolumn{10}{|c|}{ Measured GFR DTPA $\left(\mathrm{ml} / \mathrm{min} / 1.73 \mathrm{~m}^{2}\right)$} \\
\hline & \multicolumn{2}{|c|}{$\begin{array}{c}1^{\text {st }} \\
\text { quartile } \\
(n=15)\end{array}$} & \multicolumn{2}{|c|}{$\begin{array}{c}2^{\text {nd }} \\
\text { quartile } \\
(n=16)\end{array}$} & \multicolumn{2}{|c|}{$\begin{array}{c}3^{\text {rd }} \\
\text { quartile } \\
(n=15)\end{array}$} & \multicolumn{2}{|c|}{$\begin{array}{c}4^{\text {th }} \\
\text { quartile } \\
(n=15)\end{array}$} & \multicolumn{2}{|c|}{$\begin{array}{c}\text { Total } \\
(\mathrm{n}=61)\end{array}$} \\
\hline & $\mathrm{n}$ & $\%$ & $\mathrm{n}$ & $\%$ & $\mathrm{n}$ & $\%$ & $\mathrm{n}$ & $\%$ & $\mathrm{n}$ & $\%$ \\
\hline $1^{\text {st }}$ quartile & 9 & 60.0 & 1 & 6.3 & 4 & 26.7 & 1 & 6.7 & 15 & 24.6 \\
\hline $2^{\text {nd }}$ quartile & 4 & 26.7 & 6 & 37.5 & 2 & 13.3 & 4 & 26.7 & 16 & 26.2 \\
\hline $3^{\text {rd }}$ quartile & 0 & 0.0 & 6 & 37.5 & 8 & 53.3 & 1 & 6.7 & 15 & 24.6 \\
\hline $4^{\text {th }}$ quartile & 2 & 13.3 & 3 & 18.8 & 1 & 6.7 & 9 & 60.0 & 15 & 24.6 \\
\hline
\end{tabular}

Kappa $=0.336, p=0.001$

Table VI: Association between measured GFR DTPA with estimated MDRD $(n=61)$

\begin{tabular}{lcccccccccc}
\hline \multirow{2}{*}{$\begin{array}{l}\text { Estimated } \\
\text { MDRD } \\
(\mathrm{ml} / \mathrm{min} / 1.7\end{array}$} & \multicolumn{6}{c}{$\begin{array}{c}1^{\text {st }} \\
\text { quartile } \\
(\mathrm{n}=15)\end{array}$} & $\begin{array}{c}2^{\text {nd }} \\
\text { quartile } \\
(\mathrm{n}=16)\end{array}$ & $\begin{array}{c}3^{\text {rd }} \\
\text { quartile } \\
(\mathrm{n}=15)\end{array}$ & $\begin{array}{c}4^{\text {th }} \\
\text { quartile } \\
(\mathrm{n}=15)\end{array}$ & $\begin{array}{l}\text { Total } \\
(\mathrm{n}=61)\end{array}$ \\
\cline { 2 - 12 } & $\mathrm{n}$ & $\%$ & $\mathrm{n}$ & $\%$ & $\mathrm{n}$ & $\%$ & $\mathrm{n}$ & $\%$ & $\mathrm{n}$ & $\%$ \\
\hline $1^{\text {st }}$ quartile & 7 & 46.7 & 3 & 18.8 & 5 & 33.3 & 0 & 0.0 & 15 & 24.6 \\
$2^{\text {nd }}$ quartile & 3 & 20.0 & 6 & 37.5 & 4 & 26.7 & 4 & 26.7 & 17 & 27.9 \\
$3^{\text {rd }}$ quartile & 2 & 13.3 & 5 & 31.3 & 2 & 13.3 & 5 & 33.3 & 14 & 23.0 \\
$4^{\text {th }}$ quartile & 3 & 20.0 & 2 & 12.5 & 4 & 26.7 & 6 & 40.0 & 15 & 24.6 \\
\hline
\end{tabular}

Kappa $=0.125, p=0.091$

\section{Discussion}

This cross sectional study was carried out with an aim to determine the glomuler filtration rate (GFR) in healthy adult potential kidney donors in Bangladesh and to compare GFR determined by DTPA with that determined by various prediction equations. The present study findings were discussed and compared with previously published relevant studies.

In our study it was observed that the mean age was $34.31 \pm 9.46$ years, mean weight was $55.21 \pm 11.18 \mathrm{~kg}$, mean height was $160.0 \pm 9.24 \mathrm{~cm}$, mean BSA was $1.56 \pm 0.18 \mathrm{~m}^{2}$. The mean weight, height and BSA were significantly $(p<0.05)$ higher in male group. The anthropometric measures between our study population and different Indian study population were similar but quite low from that of the European study population. In Indian studies, Mohajan et al. ${ }^{\mathbf{1 1}}$, show the mean weight was $59.04 \pm 10.07 \mathrm{~kg}$, height was $1.57 \pm 9.08 \mathrm{~m}$, body surface area $1.58 \pm 0.15 \mathrm{~m}^{2}$, Srinivas et al. ${ }^{10}$ shows mean weight was $57.8 \pm 12.1 \mathrm{~kg}$, height was $1.61 \pm 9.0 \mathrm{~m}$, body surface area was $1.6 \pm 0.19 \mathrm{~m}^{2}$, respectively. European study population shows, Lin et al. ${ }^{13}$ mean weight was $78 \pm 15.7 \mathrm{~kg}$, mean height was $1.68 .5 \pm 9.4 \mathrm{~m}$, body surface area was $1.9 \pm .2$; Vervoot et $\mathrm{al}^{\mathbf{1 6}}$, mean weight was $69.9 \pm 10.1 \mathrm{~kg}$, body surface area was $1.85 \pm 0.18 \mathrm{~m}^{2}$ respectively.

In this present series it was observed that the mean serum creatinine was found $0.90 \pm 0.1 \mathrm{mg} / \mathrm{dl}$, mean $99^{\mathrm{m}} \mathrm{TcDTPA}$ renogram was found $85.4 \pm 14.6$ $\mathrm{ml} / \mathrm{min} / 1.73 \mathrm{~m}^{2}$, mean estimated CG-CCr was found $77.9 \pm 27.8 \mathrm{ml} / \mathrm{min} / 1.73 \mathrm{~m}^{2}$, the mean CG-GFR was found $77.6 \pm 20.1 \mathrm{ml} / \mathrm{min} / 1.73 \mathrm{~m}^{2}$, mean estimated GFR (MDRD) was found $84.2 \pm 18.8$ $\mathrm{ml} / \mathrm{min} / 1.73 \mathrm{~m}^{2}$. The estimated GFR using C-G and MDRD equation, mGFR by DTPA renogram also follow same trend between our study population and different Indian study population ${ }^{10,11}$.

In European studies these values were much higher than our healthy study population. Vervoot et $\mathrm{al}^{\mathbf{1 6}}$ shows that mean C-G GFR was $103 \pm 10 \mathrm{ml} /$ $\min / 1.73 \mathrm{~m}^{2}$, BSA and MDRD were $111 \pm 10$ $\mathrm{ml} / \mathrm{min} / 1.73 \mathrm{~m}^{2}$ in men. In female mean C-G GFR was $97 \pm 19 \mathrm{ml} / \mathrm{min} / 1.73 \mathrm{~m}^{2}$ and MDRD was $95 \pm 12 \mathrm{ml} / \mathrm{min} / 1.73 \mathrm{~m}^{2}$. Average GFR measured was $107 \pm 11 \mathrm{ml} / \mathrm{min} / 1.73 \mathrm{~m}^{2}$ BSA in both male and female groups. In male it was $104 \pm 9 \mathrm{ml} / \mathrm{min} / 1.73 \mathrm{~m}^{2}$ BSA, and in female measured GFR was slightly higher, $109 \pm 13.11 \mathrm{ml} / \mathrm{min} / 1.73 \mathrm{~m}^{2} \mathrm{BSA}$. Lin et al. ${ }^{13}$ measured the GFR of 100 potential kidney donors, mean ${ }^{99}$ Tc-DTPA GFR was $125.1 \pm 20.3 \mathrm{ml} / \mathrm{min} /$ $1.73 \mathrm{~m}^{2}$ BSA, mean C-G CCr. was $129.6 \pm 48.8$ $\mathrm{ml} / \mathrm{min} / 1.73 \mathrm{~m}^{2}$ BSA, mean C-G GFR was $108.9 \pm 41 \mathrm{ml} / \mathrm{min} / 1.73 \mathrm{~m}^{2}$ BSA, mean MDRD GFR was $94.5 \pm 25 \mathrm{ml} / \mathrm{min} / 1.73 \mathrm{~m}^{2}$ BSA

From above observation it is evident that eGFR in our healthy adult potential kidney donors is far lower than that of healthy adult European population. There are two possible explanations for the low GFR observed in our study population.The variables used for C-G equation is age, sex, body weight, and serum creatinine. In our study population mean weight was $55.21 \pm 11.18 \mathrm{~kg}$ in 30 years age group. In Vervoot et al $^{\mathbf{1 6}}$, mean weight was $69.9 \pm 10.1 \mathrm{~kg}$. In both studies serum creatinine was same. In our study population, mean $\mathrm{C}-\mathrm{GCrCl}$ was $77.9 \pm 27.8 \mathrm{ml} / \mathrm{min} / 1.73 \mathrm{~m}^{2}$ BSA but it was $97.1 \mathrm{ml} / \mathrm{min} / 1.73 \mathrm{~m}^{2}$ BSA in Vervoot et $\mathrm{al}^{16}$. So due to anthropometric measures, eGFR is low in our population using $\mathrm{C}-\mathrm{G}$ equation. Abbreviated MDRD equation was developed from stepwise multiple regression. The data obtained from 1,628 Americans of which 983 were white and 645 were black. Mean weight was $79.6 \pm 16.8 \mathrm{~kg}$ and body surface area was $1.91 \pm 0.23 \mathrm{~m}^{2}$. Black Americans have greater muscle mass and GFR than white 
Americans. So a constant is created in the MDRD equation for black Americans. MDRD study population includes none from South Asian population, whose height, weight, body surface area and muscle mass all far lower than that of the white or black Americans.

Another issue is that our study population truly has low GFR with respect to that of European population. There are two explanations for the low GFR observed in our population. First, the low protein intake in this population may explain lower GFR. Dietary protein intake has been recognized as a modulator of GFR for over a half a century ${ }^{17}$.

Secondly low nephron number at birth associated with low birth weight could be another explanation for low GFR observed in South Asian population. Mothers, especially in rural areas have low BMI and thought to be chronically malnourished. The maternal and fetal malnutrition is associated with low birth weight and smaller size of organs such as pancreas and kidneys ${ }^{18}$.

The performance of CG equation and MDRD equation to determine GFR in healthy population is misleading. In some studies MDRD equation has been reported to be more accurate than $\mathrm{C}-\mathrm{G}$ equation $^{19-21}$, where as other studies have found that these two may be similar ${ }^{22}$. But the MDRD equation and C-G equation have both been reported to be less accurate in healthy population without kidney disease.

Estimated CG-CCr, estimated MDRD and estimated CG-GFR were compared by measured GFR DTPA according to quartile and found poor agreement and also the value of Kappa coefficients $0.104,0.125$ and 0.366 respectively, which showed no association with measured GFR. As a consequence, the agreement between the two consecutive measurements was poor. Therefore, the results of present findings of estimated CG-CCr, estimated MDRD and estimated CG-GFR have no association with measured GFR DTPA.

Limitation of the study: Duration of study was only one year. It was very difficult to do such a big study within this short time. Total study population was relatively small who were evaluated as live related kidney donors. So GFR determined by DTPA in this study may or may not predict population GFR. If the study population was more, data would be more representative. DTPA renogram by measuring plasma level of radiopharmaceuticals is a better assessor of GFR in comparison to DTPA renogram by gamma camera, but only gamma camera method was available in the current study.
Recommendations: A larger study is needed to be conducted to verify the validity of the predicting equations in our population among both healthy population and patients with chronic kidney disease.

A larger study is demanded to evaluate healthy donors' renal function by DTPA method and if the results are in agreement with the present one, DTPA renogram should be recommended as the method of determination of GFR in live related kidney donors instead of predicted equations.

Conclusion: This study was undertaken to determine the glomerular filtration rate (GFR) in healthy adult potential kidney donors in Bangladesh and to compare GFR measured by DTPA with GFR estimated by various equations.

NKF KDOQI ${ }^{\mathrm{TM}}$ currently recommend the use of predictive equation to estimated GFR the healthy Kidney donors as well as detection and assessment progression of CKD. But this study result indicates poor performance of these equations in evaluation of renal function among healthy population and also raise question regarding validity of these equations for assessment of renal function in chronic kidney disease in our populations

\section{References}

1. Glassock, RJ, 'Response to 'Need for a more realistic cut off GFR value to define chronic renal failure', Kidney International, 2008; 73: 1326.

2. Petersen, LJ, Petersen, JR, Tallerphuus, U, Moller, ML, Ladefoged, SD, Mehlsen, J and Jensen, HA, 'Glomerular filtration rate estimated from the uptake of ${ }^{99 \mathrm{~m}}$ Tc-DTPA renogram in chronic renal failure', Nephrol, Dial Transplant, 1999; 14(7): 1673-8.

3. Perrone, RD, Steinman, TI, Beck, GJ, Skibinski, CI, Royal, HD, Lawlor, M, Hunsicker, LG, 'Utility of radioisotopic filtration markers in chronic renal insufficiency: simultaneous comparison of 125Iothalamate, 169Yb-DTPA, 99mTc-DTPA, and inulin', Am J Kidney Dis, 1990; 16: 224-35.

4. Rehling, M, Moller, ML, Thambrup, B, Lund, JO, Trap-Jeson, J, 'Simulaneous measurement of renal clearance and plasma clearance of ${ }^{99 \mathrm{~m}} \mathrm{Tc}$-labelled diethylenetriaminepenta-acetate, $\quad{ }^{51} \mathrm{Cr}$-labelled ethylenedia- minetetra -acetate and inulin in man', Clin. Sci, (London), 1984; 66: 613-619.

5. Blaufox MD, Aurell M, Bubeck B, Fommei E, Piepsz A, Russell C, Taylor A, Thomsen HS, Volterrani $\mathrm{D}$, 'Report of the Radionuclides in Nephrourology Committee on Renal Clearance J Nucl Med 1996; 37(11): 1883-1890.

6. Rehling M, Jensen JJ, Scherling B, Egeblad M, Lønborg-Jensen H, Kanstrup I, Dige-Petersen H Evaluation of renal function and morphology in children by $99 \mathrm{~m}$ Tc-DTPA gamma camera renography. Acta Paediatr Scand, 1989; 78(4): 601-607. 
7. N. Prasad, S. Barai, S. Gambhir, D. S. Parasar, M. Ora, A. Gupta, and R. K. Sharma Comparison of glomerular filtration rate estimated by plasma clearance method with modification of diet in renal disease prediction equation and Gates method Indian J Nephrol. 2012; 22(2): 103-107.

8. Shore RM, Koff SA, Hayes JR 1984. Glomerular filtration rate in children: determination from the Tc99m-DTPA renogram. Radiology.1984;151(3):627-33.

9. National Kidney Foundation. K/DOQI clinical practice guidelines for chronic kidney disease: evaluation, classification, and stratification. Am J Kidney Dis. 2002; 39: 266.

10 Srinivas, S, Annigeri, RA, Mani, MK, Rao, BS, Kowdle, PC, Seshadri, R, 'Estimation of glomerular filtration rate in South Asian healthy adult kidney donors', Nephrology Carlton Vic, 2008;13(.5):440-446.

11. Mahajan, S, Mukhiya, GK, Singh, R, Tiwari, SC, Kalra, V, Bhowmik, DM, Gupta, S, Agarwal, SK, Dash, SC, 'Assessing glomerular filtration rate in healthy Indian adults: a comparison of various prediction equations', J Nephrol, 2005; 18: 257- 261.

12. Cockcroft DW, Gault MH, 'Prediction of creatinine clearance from serum creatinine' Nephron. 1976; 16(1): 31-41.

13. Lin, J, Knight, E, Hogan, ML, Singh, AK, 'A comparison of prediction equations for estimating glomerular filtration rate in adults without kidney disease', J Am Soc Nephrol, 2003; 14: 2573-80.

14. Levey AS, Bosch JP, Lewis JB, Greene T, Rogers N, Roth D. A more accurate method to estimate glomerular filtration rate from serum creatinine: a new prediction equation. Ann Intern Med, 1999a; 130: 46170.

15. Levey AS, Bosch JP, Lewis JB, Greene T, Rogers N, Roth D. For the Modification of Diet in Renal Disease Study Group: A more accurate method to estimate glomerular filtration rate from serum creatinine: a new prediction equation. Ann Intern Med. 1999b; 130: 877884.

16. Vervoort, G, Willems, FL, Wetzels, JF, 'Assessment of glomerular filtration rate in healthy subjects and normoalbuminuric diabetic patients: validity of a new (MDRD) prediction equation', Nephrol Dial Transplant, 2002; 17: 1909-13.

17. King AJ and Levey AS, 'Dietary protein and renal function', J Am Soc Nephrol. 1993; 3: 1723-1737.

18. Yajnik CS Early life origins of Insulin resistance and type 2 diabetic in India and other Asian countries. J Nutrition, 2004; 134: 205-210.

19 Froissart M, Rossert J, Jacquot C, Paillard M, Houillier P., 'Predictive performance of the Modification of Diet in Renal Disease and Cockcroft-Gault equations for estimating renal function', J Am Soc Nephrol, 2005; 16: 763-73.

20. Poggio, ED, Wang, X, Greene, T, Van, Lente, F, Hall, PM, 'Performance of the Modification of Diet in Renal Disease and Cockcroft-Gault equations in the estimation of GFR in health and in chronic kidney disease', J Am Soc Nephrol, 2005; 16: 459-66.

21. Rule, AD, Gussak, HM, Pond, GR, Bergstralh, EJ, Stegall, MD, Cosio, FG, Larson, TS, 'Measured and estimated GFR in healthy potential kidney donors', Am J Kidney Dis, 2004; 43: 112-9.

22. Verhave JC, Fesler P, Ribstein J, du Cailar G, Mimran A. 2005, Estimation of renal function in subjects with normal serum creatinine levels: influence of age and body mass index. Am J Kidney Dis, 2005; 46: 233-41.

23. Landis JR and Koch GG, 'The measurement of observer agreement for categorical data' Biometrics 1977; 33(1): 159-174. 